\title{
Emerging US Government and Military Literature on the U.S. Space Force
}

Bert Chapman

Purdue University

\section{Abstract}

Established in 2018, the U.S. Space Force is the newest branch of the U.S. military. The reality of space as an arena for international geopolitical and military competition has been around for decades in scholarly literature and publicly accessible government information resources. This work examines recently published U.S. Government and military literature on Space Force. These works examine various economic, military, and political aspects of this entity and how it may affect U.S. national security policy in years to come. Public opinion polls on space force are also included. An additional objective of this work is enabling readers to use their analysis of this lecture to explore potential business contracting opportunities, contacting their congressional representatives, and participating in the federal regulatory process to express their views on Space Force developments.

Keywords: United States Space Force, military astronautics, space policy, government oversight, government contracting, public awareness

\section{Literatura militar y gubernamental emergente de EE. UU. Sobre la Fuerza espacial de EE. UU.}

\section{RESUMEN}

Establecida en 2018, la Fuerza Espacial de EE. UU. Es la rama más nueva del ejército de EE. UU. La realidad del espacio como arena para la competencia geopolítica y militar internacional ha existido durante décadas en la literatura académica y en los recursos de información del gobierno de acceso público. Este trabajo examina la literatura militar y del gobierno de EE. UU. Recientemente publicada sobre la Fuerza Espacial. Estos trabajos examinan varios aspectos económicos, militares y políticos de esta entidad y cómo puede afectar la política de seguridad nacional de Estados Unidos en los próximos años. También se incluyen encuestas de opinión 
pública sobre la fuerza espacial. Un objetivo adicional de este trabajo es permitir a los lectores utilizar su análisis de esta conferencia para explorar posibles oportunidades de contratación comercial, contactar a sus representantes en el Congreso y participar en el proceso regulatorio federal para expresar sus puntos de vista sobre los desarrollos de la Fuerza Espacial.

Palabras clave: Fuerza espacial de los Estados Unidos, astronáutica militar, política espacial, supervisión gubernamental, contratación gubernamental, conciencia pública

\section{关于美国太空军的新兴美国政府及军事文献}

\section{摘要}

成立于 2018年, 美国太空军是美国最新的军事分支。几十年 里, 学术文献和公共存取的政府信息资源都对太空作为国际 地缘政治和军事竞争的舞台一事进行了研究。本文分析了近 期发表的有关太空军的美国政府及军事文献。这些文献分析 了关于太空军的不同经济方面、军事方面、政治方面, 以及 其如何能影响未来几年里美国的国防政策。（本文）还包括 了关于太空军的民意测验。本文的一个额外目标是帮助读者 使用各自对这篇文章的分析, 来探究潜在的商业承包机遇、 联系各自的国会代表、并参与联邦监管过程, 以期表达各自 关于太空军发展的观点。

关键词: 美国太空军, 军事宇航学, 太空政策, 政府监督, 政府承包，公共意识

\section{Introduction}

$\mathrm{E}$ stablished in 2018, the U.S. Space Force is the newest branch of the U.S. military. The reality of space as an arena for international geopolitical and military competition has been around for decades in scholarly literature and publicly accessible government information resources. This work examines recently published U.S.
Government and military literature on Space Force. These works examine various economic, military, and political aspects of this entity and how it may affect U.S. national security policy in years to come. Public opinion polls on space force are also included. An additional objective of this work is enabling readers to use their analysis of this lecture to explore potential business contracting opportunities, contacting their con- 
gressional representatives, and participating in the federal regulatory process to express their views on Space Force developments.

\section{Recent Legislative Developments}

The United States Space Force (USSF) is the newest branch of the U.S. armed forces. Its establishment has been a long time in development and its future direction remains unknown. However, it is possible to begin gaining an understanding of its nature and mission through publicly accessible U.S. Government and military information resources. On December 18, 2018, President Donald Trump sent a memorandum to the Secretary of Defense authorizing establishment of United States Space Command as a unified geographic combatant command (White House, 2018). USSF was statutorily established in the Fiscal Year (FY) 2020 National Defense Authorization Act signed by Trump on December 19, 2020. USSF was established to be led by a presidentially appointed and Senate-confirmed Chief of Space Operations (CSO) from Air Force officers serving at presidential pleasure who is also a member of the Joint Chiefs of Staff. USSF organizational functions and duties include:

- Providing U.S. freedom of operation in, from, and to space;

- Being organized, trained, and equipped to engage in prompt and sustained space operations;
- Protecting U.S. interests in space;

- Deterring aggression in, from, and to space; and

- Conducting space operations (Public Law 116-92).

This law established the first U.S. armed service branch since the July 26 , 1947 National Security Act establishing the U.S. Air Force (Public Law 80-253). U.S. military service involvement in space has been a hallmark characteristic of U.S. national security policymaking for many decades prior to USSF. Each armed service branch has engaged in extensive space policymaking and the U.S. intelligence community also uses space assets to further national security objectives (Chapman, 2008; Laurie, 2001; Ruffner, 1995; Spires, 2007).

USSF currently and the CSO are headquartered in the Pentagon (U.S. Space Force, 2020). Its organizational directorates and their responsibilities include:

- Executive Staff providing command and control and executing major acquisition decisions.

- USSF/S1 Directorate of Manpower, Personnel, and Services providing manpower resource solutions and supporting airmen with USSF.

- USSF S2/3/6 Directorate of Integrated Air, Space, Cyberspace, and Intelligence, Surveillance, and Reconnaissance (ISR) Operations integrating space and cyberspace operations with air, land, and maritime domains. 
- USSF/S4 Directorate of Logistics, Engineering, and Force Protection providing cyberspace weapons systems sustainment solutions and coordinating infrastructure and force protection from Air Force installations and mission support center; and

- USSF/S5/8/9 Directorate of Strategic Plans, Programs, Requirements, and Analysis coordinating space and cyberspace planning; analyzing space and cyberspace requirements; and developing space and cyberspace policy. (U.S. Space Force 2020b)
USSF facilities are located at Buckley Air Force Base (AFB), CO; Los Angeles AFB, CA; Patrick AFB, FL; Peterson AFB, CO; Schriever AFB, CO; and Vandenberg, AFB, CA (U.S. Space Force 2020c). Its initial allocated operation and maintenance budget for FY 2020 was $\$ 72,436$ million (Public Law 116-92). Congressional authorizing committees had not reached agreement on FY 2021 space force funding as of October 1, 2020. In its defense spending report, the House Appropriations Committee included the following figures for the Space Force's congressional budget request, its previous year funding level, and the House's funding recommendations for the following categories:

Operation and Maintenance

\begin{tabular}{|c|c|c|c|}
\hline $\begin{array}{c}\text { FY 2020 } \\
\text { Appropriation }\end{array}$ & $\begin{array}{c}\text { FY 2021 Budget } \\
\text { Request }\end{array}$ & $\begin{array}{c}\text { Committee Year } \\
\text { Recommendation }\end{array}$ & $\begin{array}{c}\text { Change from Budget } \\
\text { Request }\end{array}$ \\
\hline$\$ 40,000,000$ & $\$ 2,531,294,000$ & $\$ 2,498,544,000$ & $\begin{array}{r}-\$ 32,750,000 \\
\text { (House Report 116-453) }\end{array}$ \\
\hline
\end{tabular}

Procurement

\begin{tabular}{|r|c|c|c|}
\hline $\begin{array}{c}\text { FY 2020 } \\
\text { Appropriation }\end{array}$ & $\begin{array}{c}\text { FY 2021 Budget } \\
\text { Request }\end{array}$ & $\begin{array}{c}\text { Committee Year } \\
\text { Recommendation }\end{array}$ & $\begin{array}{c}\text { Change from Budget } \\
\text { Request }\end{array}$ \\
\hline 0 & $\$ 2,446,064,000$ & $\$ 2,289,934,000$ & $\begin{array}{r}-\$ 156,030,000 \\
\text { (House Report 116-453) }\end{array}$ \\
\hline
\end{tabular}

Research, Development, Test, and Evaluation

\begin{tabular}{|c|c|c|c|}
\hline $\begin{array}{c}\text { FY 2020 } \\
\text { Appropriation }\end{array}$ & $\begin{array}{c}\text { FY 2021 Budget } \\
\text { Request }\end{array}$ & $\begin{array}{c}\text { Committee Year } \\
\text { Recommendation }\end{array}$ & $\begin{array}{c}\text { Change from Budget } \\
\text { Request }\end{array}$ \\
\hline 0 & $\$ 10,327,595,000$ & $\$ 10,187,840,000$ & $\begin{array}{r}-\$ 139,755,000 \\
\text { House Report 116-453) }\end{array}$ \\
\hline
\end{tabular}

The House Committee went on to stress its desire that USSF devote its budget resources to assure space capa- bilities can support combat commands during conflict and that more time, attention, and funding will be focused on 
funding support capabilities including the weather satellite program and future strategic communications program. This document expressed concern that the Air Force has no Senate-confirmed civilian leader focusing exclusively on space with authority over acquisition, budget, and long-term planning. Additional concern was expressed over transferring Army, Navy, and other defense agencies into USSF saying it would not support such transfers without assurance that they will not negatively affect these organizations or national security (House Report 116-453).

The Senate's FY 2021 defense spending report on USSF made the following budget allocations:

\begin{tabular}{|l|l|}
\hline Operation and Maintenance & $\$ 2,530,894$ \\
\hline $\begin{array}{l}\text { Research, Development, Test, } \\
\text { and Evaluation }\end{array}$ & $\$ 10,301,095$ \\
\hline Procurement & $\begin{array}{l}\$ 2,458,564 \text { (U.S. Congress, Senate } \\
\text { Committee on Armed Services, } \\
2020 \mathrm{a}) .\end{array}$ \\
\hline
\end{tabular}

Additional provisions in the Senate USSF report stress the vital importance of strategic satellite communication to national security and the presence of a 7-year gap in resilient capability coverage; problematic communications in the northernmost latitudes; and developments in low and medium earth orbital communications which could enhance communication quality in these regions. Further language in this report included prohibiting the involuntary transfer of civilian or military personnel into USSF out of concern that such transfers would be counterproductive to successful deployment; encouraging the development of mobile launch capabilities to mitigate existing threats from hostile forces and natural disasters in fixed range launch infrastructure; and requiring developing and demonstrating a proliferated lowearth orbit sensing, tracking, and data transport architecture along with integrating next generation space capabilities including hypersonic and ballistic missile tracking space sensors payloads. This version also required the Secretary of the Air Force to submit to Congress a report on the potential for countries such as China to enter the global commercial space launch market by January 1,2021 . The extent that House and Senate committee reports on space launch will be reconciled remains uncertain (U.S. Congress. Senate Committee on Armed Services, 2020).

\section{Air University Press Literature}

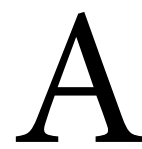
ir University at Maxwell AFB, AL is the U.S. Air Force's professional military educational institution. Its multiple academic and research entities produce historical perspectives and contemporary analysis of subjects pertaining to aerospace 
operations. This has been particularly true for space warfare and the USSF with many of these publications freely available through Air University Press. Publications postulating on military uses of space to advance U.S. and allied aerospace interests have produced for multiple decades and the subsequent section will document some of these examples. Mowthorpe's 2001 analysis provides detailed coverage of U.S. military space policy beginning with the Eisenhower Administration (Mowthorpe, 2001).

Military spacepower was a key feature of Air and Space Power Journal in November/December 2014. Hayden stressed the need for spacepower to develop a war fighting doctrine comparable to the air, land, and sea-power doctrines developed by Guido Douhet, Karl von Clausewitz, and Alfred Thayer Mahan. This analysis stressed that current joint U.S. military doctrine defined space superiority as "the degree of dominance in space of one force over any others that permits the conduct of its operations at a given time and place without prohibitive interference from space-based threats." Hayden also asserted that space professionals cannot afford to wait for the time when the battlefield is shaped from space but must develop a coherent space warfighting doctrine to prevent disastrous effects on U.S. lives and interests (Hayden, 2014).

This journal's same issue saw Cesul argue that the U.S. should develop a space control strategy to:

1. Control the electromagnetic (EM) spectrum over and within a locale at a time and severity of our choosing to enable U.S. freedom of action and information dominance

2. Counter, both kinetically and non-kinetically, adversary space and counterspace systems directly threatening U.S. assets in space or terrestrially, with preference to options that minimize disruptions to U.S. and allied capabilities while defeating the enemy kill chain as early as possible in a crisis situation; and

3. Utilize a command, control, communications, computers, intelligence, surveillance, and reconnaissance (C4ISR) posture (including the development of SSA architecture) that allows the United States to develop and execute space control plans and operations, specifically provide indications and warnings of catastrophic space events, discover indications and warning of impending hostile space control activities, maintain custody of threat systems, and deliver intelligence to support space control options (Cesul, 2014).

Military space threats from great power rivals such as China and Russia are generally recognized as the biggest concerns of U.S. military space policy planning. It is necessary, however, to think outside the usual parameters of military strategic planning when contemplating military threat scenarios. An example of this is provided by a work explaining that threats to U.S. interests in space may originate from non-state actors aspiring to challenge the existing in- 
ternational order, overturn political and economic situations in their countries, and profiting from insufficient attention paid to them by international nations. Such scenarios could involve attacking Global Positioning System (GPS) assets which could have spillover effects against U.S. military and civilian assets, attacking astronauts or satellite communication links, using cyberattacks to decapitate space launch facilities, commercial competitors attacking each other, and the originators of these attacks being individuals and organizations who may not easily subject to criminal prosecution and punishment under national and international law (Miller, 2019).

Whitney, Thompson, and Park stress how U.S. national security space requirements have evolved since the 1982 establishment of Air Force Space Command. They note China and Russia have increased their military space emphasis from organizational structure and spending in kinetic physical and nonphysical kinetic threats to countering the U.S. in space. During 20152016, China established its Strategic Support Force (SSF) to coordinate its military space, cyber, and electronic warfare capabilities. SSF established a Space System department charged with providing the military with communications, computers, intelligence, surveillance, and reconnaissance capabilities as part of an orbital counterspace mission which could include radiofrequency systems to jam satellite communications and GPS and using malicious software to disrupt computer network operations in satellite tracking and ground control systems.
During 2015, Russian military space forces were subordinated into the Russian Aerospace Forces with responsibility for monitoring space objects to identify and prevent potential space threats to Russia and handling spacecraft launches and controlling and managing satellite systems for civilian and military missions. Moscow is also likely to use lasers to temporarily dazzle or permanently blind optical sensors while microwave weapons can disrupt or disable electronics on Low Earth Orbit remote-sensing and missile defense satellites. Recommendations made in 2017 by U.S. Strategic Command commander General John Hyten (now Vice-Chair of the Joint Chiefs of Staff) for establishing a military space force included:

- Overseeing the acquisition, development, and deployment of military space and tactically employed strategic level and ground control segments;

- Acting as the single authority for enterprise-wide defense system architect and integrator for overall space architecture;

- Creating a rapid space capabilities office to quickly design and acquire major new and affordable space capabilities;

- Establishing a national security space executive committee providing strategic and policy guidance for all DOD space acquisitions (Whitney, Thompson, Park, 2019) 
Townsend notes that current U.S. military doctrine includes no definition of space power; asserts that developing a theory of space power is difficult because space is an untested domain unlike the sea and that space is an untested domain due to the absence of empirical evidence on conflict in space; contends that space command is achieved through presence, coercion, and force; and a key to space power involves "acquiring the human and technical resources to increase one's freedom of action, while aiming to reduce an opponent's." This treaties goes on to maintain that space power alone cannot determine terrestrial conflict's outcome or attain terrestrial political objectives; that the country with the most significant commercial space industrial base will have the largest orbital presence and the greatest amount of space control and power; military space power strategy must account for the presence of commercial satellites; rival countries recognition of acute U.S. military dependence on space assets has spurred redefining space as a war-fighting domain; and that achieving information dominance as an integral factor in achieving victory or defeat will be an integral factor in increasing the strength of the case for establishing a separate Space Force (Townsend, 2019).

Grosselin observed that during an outgoing interview in May 2019 that Secretary of the Air Force Heather Wilson identified developing a warfighting culture as the Air Force space mission's most pressing challenge. The author contends that the Air Force and USSF must transition from a space serving culture to a space-warfighting culture with war-fighting cultures being adversary centric focusing on a competent and lethal adversary threatening American interests. Consequently, USSF must handle uncertainty by seizing the initiative through decentralized execution and mission command principles; pursuing innovation by continuously seeking military advantage over adversaries; assuming key roles as tacticians, mission planners, and battle managers; and measuring success by winning in a competitive environment (Grosselin, 2020).

This treatise concludes by stressing three themes including: space being vital to national power and prosperity, military space forces being an interdependent element of the Joint Force, and military space force demanding unique expertise. Specific aspects of each of these criteria include national space power involves exploiting economic, information, military, and political elements and information derived from space-based remote sensing being a core of U.S. global information dominance; without space capabilities joint operations revert to bloody early twentieth century Industrial Age warfare featuring mass concentration of force-on-force violence and indiscriminate destruction; and space mastery including the entire space environment encompassing space flight physics and engineering and predictive understanding of the interests and behaviors of civil, commercial, and foreign space actors (Grosselin, 2020).

In their proposed legislative framework for USSF, Grant and Neil 
propose amending Title 10 Section F of the United States Code with the following language describing USSF's primary duties:

Subject to the requirements of international law, the Space Force shall enforce or assist in the enforcement of all applicable federal laws in, on, and surrounding terrestrial spaceports and those locations in space subject to the jurisdiction of the United States. It shall engage in space surveillance or interdiction to enforce or assist in the enforcement of the laws of the United States. It shall administer laws and promulgate and enforce regulations for the promotion of life and safety of life and property in space. It shall develop, establish, maintain, and operate, with due regard to the requirements of national defense, rescue facilities, as needed, for the promotion of safety in space. It shall, in coordination with NASA, engage in scientific research and exploration of space and heavenly bodies. It shall maintain a state of readiness to function as a specialized service in the joint force in wartime, including the fulfillment of Space Defense command responsibilities (Grant and Neil, 2020).

\section{Recent DOD and USSF Policy Documents}

$\mathrm{P}$ olicy documents on U.S. military space policy were produced by DOD and the White House even before USSF's statutory establishment. DOD Directive 5100.96 dated June 9, 2017 established policy, assigned responsibilities, and established relationships for governing the DOD Space Enterprise; established the Defense Space Council; established the position of Principal Department of Defense Space Advisor (DPSA); and designated the Secretary of the Air Force as PDSA. PDSA responsibilities included monitoring and overseeing the performance of DOD's space portfolio including assessing space-related threats, requirements, and architectures, programs, and their synchronization; conducting an annual strategic assessment including prioritized programmatic choices for space capabilities; and overseeing development of long-term mission area capabilities including program and budget submissions (U.S. Department of Defense, 2017).

Space Policy Directive 4 establishing USSF was issued by President Trump on February 19, 2019. It began by stressing how integral space has become to American economic prosperity, national security, and modern warfare. This document proceeded to note that while the U.S. has historically maintained a space technology edge over potential adversaries that those adversaries are advancing their space capabilities and actively developing methods to deny the U.S. use of space in a crisis or conflict. Trump directed DOD to develop USSF to deter and counter threats in space with USSF being authorized to organize, train, and equip military space forces to ensure the U.S. has unrestricted access and freedom to 
operate in space and provide critical capabilities to joint and coalition forces in peacetime and across the conflict spectrum (Space Policy Directive 4, 2019).

Space Policy Directive 5 issued on September 4, 2020, enumerated cybersecurity principles for space systems. It began by stressing how space systems rely on information and networks from design conceptualization through launch and flight operations and that such systems can be degraded through spoofing sensor data; corrupting sensor systems; jamming or sending unauthorized guidance and control commands; injecting malicious code; and conducting denial-of-service attacks. Consequently, this directive urged developing space systems and their supporting infrastructure, including software, using risk-based cybersecurity-informed engineering. Additional attributes of space cybersecurity include allowing operators or automated control systems to retain or recover positive control of space vehicles; protecting against unauthorized access to critical space vehicle functions; protecting ground systems by adopting cybersecurity best practices; managing supply chain risks affecting space system cybersecurity through tracking manufactured products; requiring sourcing from trusted suppliers; identifying counterfeit, fraudulent, and malicious equipment, and accessing all available risk mitigation measures (Space Policy Directive 5, 2020).

June 2020 saw USSF issue its doctrinal capstone publication. This aspirational document stressed the following as U.S. military spacepower guiding principles:
- The U.S. desires a peaceful, secure, stable, and accessible space domain. Strength and security in space enables freedom of action in other warfighting domains while contributing to international security and stability. The U.S. must adapt its national security space organizations, doctrine, and capabilities to deter and defeat aggression and protect national interests in space.

- The space domain is the area above the altitude where atmospheric effects on airborne objects become negligible. The value of the space domain arises from an ability to conduct activities with unrivaled reach, persistence, endurance, and responsiveness, while affording legal overflight of any location on the earth. Because of these attributes, space power is inherently global.

- Military space forces are the warfighters who protect, defend, and project space power. They provide support, security, stability, and strategic effects by employing spacepower in, from, and to the space domain. This necessitates close collaboration and cooperation with the U.S. Government, Allies, and partners and in accordance with domestic and international law.

- Not only are space operations global, they are also multi-domain. A successful attack against any one segment (or combination of segments), whether terrestrial, link, or space, of the space architecture can neutralize a space capability; 
therefore, space domain access, maneuver, and exploitation require deliberate and synchronized defensive operations across all three segments.

- As a lean, mission-focused, digital service, the United States Space Force values organizational agility, innovation, and boldness. Elevating these traits starts with empowering small teams and prizing measured risk-taking as opportunities to rapidly lean and adapt (U.S. Space Force 2020(d).

USSF cornerstone responsibilities include preserving freedom of action, enabling joint lethality and effectiveness, and provide independent options. These responsibilities are fed by these core competencies: space security, combat power projection, space mobility, and logistics, information mobility, and space domain awareness. These core competencies mandate specialization in orbital warfare, space electromagnetic warfare, space battle management, space access and sustainment, military intelligence, cyber operations, and engineering/ acquisitions (U.S. Space Force 2020(d).

This publication also stressed that military space forces need to study select engagements, battles, and campaigns in depth in order to understand warfare's human element. It notes studying warfare from any domain in depth allows warfighters to better forecast pressures high-intensity conflict will place on their combat responsibilities, how decisions were made, and how uncertainty, friction, and chaos influenced those decisions. Such knowledge highlights how luck, timing, and biases impact the course of a military engagement. USSF's capstone doctrine also stresses that military space forces must study warfare in its political and social context based on the imperative of understanding war as an extension of national policy within the context of political goals combatants aim to achieve (U.S. Space Force 2020(d).

This same month saw DOD issue its Defense Space Strategy Summary. It began by noting space's emergence as a distinct warfighting domain, demanding enterprise-side changes to policies, strategies, operations, and investments, capabilities, and expertise for a new strategic environment. This summary noted that China and Russia have weaponized space to reduce U.S. and allied military effectiveness and challenge freedom of operation in space. Consequently, exponential increases in global commercial and international space activities enhance the complexity of the space environment (U.S. Department of Defense, 2020a).

Areas of military space emphasis for USSF include building a comprehensive military advantage in space; integrating military spacepower into national, joint, and combined operations, shaping the strategic environment, and cooperating with allies, partners, industry, and other U.S. Government departments and agencies. Specific implementation of these aspirations involves developing and documenting doctrinal foundations of military space power, 
developing and expanding space warfighting expertise and culture, developing and fielding capabilities countering hostile use of space; integrating space warfighting operations, intelligence, capabilities, and personnel into military plans and staff; planning, exercising, and executing joint and combined operations across the conflict spectrum; informing international and public audiences of growing hostile threats in space; deterring adversary aggression against the space interests of the U.S. and its allies and commercial interests; coordinating space messaging; promoting standards and behavior space norms favorable to the U.S. and its allies; aligning with allies and partners on space policy; and expanding cooperative research, development, and acquisition with allies and partners (U.S. Department of Defense, 2020a).

\section{Business Contracting Opportunities}

$\mathrm{E}$ stablishing a new federal agency provides potentially lucrative contracting opportunities for the private sector and for academic research grants for eligible entities. System for Awards Management (SAM) is the U.S. Government's website for doing business with the federal government. There is limited information on space force contracting opportunities in SAM as of early October 2020. This is likely to change as USSF gets organized. It is currently possible to find information on SAM registered companies such as Space Exploration Technologies Corporation (popularly known as Space-X).
Types of information on Space-X available in SAM its registration status including activation and expiration dates, the name of the Space-X employee responsible for updating its information, and the organization's physical address (System for Award Management, 2020). On August 7, 2020 USSF and the National Reconnaissance Office (NRO) awarded phase two launch contracts to United Launch Alliance (ULA) and Space-X for launch service contracts worth $\$ 337$ million and $\$ 316$ million respectively between Fiscal Years 20202024. Intended launch dates are in the second and fourth quarters of Fiscal Year 2022 (U.S. Space Force, 2020e).

Grants.gov provides one-stop access for individuals, institutions, and organizations seeking posted or forecasted federal grants from USSF and other agencies. An example of a recently posted USSF related grant is Funding Opportunity Number FA9453-17-S-0005 entitled Research Options for Space Enterprise Technologies (RESOT). This grant was posted on February 14, 2018 by the Air Force Research Laboratory (AFRL) at Kirtland, AFB, NM. The grant notes that AFRL's Space Vehicles Directorate wishes to receive proposals from entities wanting to offer advance state of the art technology and scientific knowledge supporting space systems including payload adapters, on-orbit systems, communications links, ground systems, and user equipment. The contract's estimated program funding is $\$ 467$ million with the application closing date being September 28, 2022. Additional contract attributes include basic and advanced research, advanced com- 
ponent and technology development, prototyping, and system development and demonstration. Such development and demonstration should span the range from concept and laboratory experimentation to testing/demonstration in a relevant environment involving design, development, analysis, fabrication, integration, characterization, testing/ experimentation, and demonstration of hardware and software products. AFRL employee Ambros Montoya is listed as the contact individual and his e-mail is provided. Technical and legal requirements are also included in each grant (Grants.gov, 2018).

Documentation of federal government spending by budget function, agency spending, and object class is provided by usaspending.gov/ from Fiscal Year 2008-present. An example of a current USSF contract and its spending data and history is provided by contract FA251718F9021. Awarded by DOD to Apogee Engineering Ltd, LLC of Colorado Springs, CO on July 19,2018 , this $\$ 4.5$ million contract was issued by Air Force Space Command. Its purpose involved Apogee preparing training product development support for the ready space crew program and space mission force to create training products for the $460^{\text {th }}$ Operations Support Squadron, $1^{\text {st }}$ Space Operations Squadron, and $4^{\text {th }}$ Space Control Squadron and provide assistance to Air Force Space Command Headquarters on implementing space mission force efforts. The contract's initial end date was August 26, 2020 with its current end date being February 26, 2024 (Usaspending. gov, 2020).

\section{Legal and Regulatory Resources}

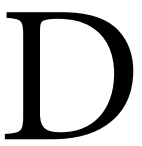
espite its recent establishment legal and regulatory information resources on USSF are emerging. U.S. federal laws are codified in the United States Code (USC) which is broken up into 54 different title or subject areas. Laws pertaining to USSF are in Title 10 of the USC which covers U.S. military forces. Sections 9081-9083 of Title 10 cover USSF with section 9081 covering the principal reasons for USSF's establishment; section 9082 covering the role played by the CSO who receives a four year presidential appointment and enumerates the $\mathrm{du}$ ties of this individual; and section 9083 establishes an office career field for space authorizing the Secretary of the Air Force to develop career paths for officers with technical competence in space-related matters including developing space doctrine and concepts of operations; developing space systems; and operating space systems. This statutory imprint and corpus will expand in subsequent years as USSF does with congressional direction and depending on developments in U.S. and global military space activities and technologies (U.S. House of Representatives, Office of Law Revision Counsel, 2020).

It remains to be seen how USSF will impact U.S. military and international law though some literature on this subject is emerging. Some scholars argue that military activity in space is already prohibited and should remain prohibited, while others argue that states can use force in space for self-defense and resolving international dis- 
putes and that space weapons provide greater precision, fewer casualties and destruction, and more effective crisis bargaining between states (Yoo, 2020; Ramey, 2000; King, 2016).

Federal regulations on USSF and business contracting will be important study fields for those analyzing USSF activities. These regulations provide legally binding guidance to USSF and other federal agencies on how to implement congressionally passed and presidentially signed laws. The complete text of federal regulations can be found in the Code of Federal Regulations (CFR) which is published collaboratively by the National Archives Office of the Federal Register and the U.S. Government Publishing Office and updated annually on a rotating basis throughout the year. The CFR is broken down into 50 different titles or subject areas (U.S. Government Publishing Office, 2020a, U.S. National Archives and Records Administration, 2020a).

Currently there are no specific USSF regulations in the CFR though that will inevitably change as this force is stood up and developed. Possible locations for USSF regulations in the CFR include Title 32 Parts 800-1099 which cover the U.S. Air Force (U.S. Government Publishing Office 2020b, U.S. National Archives and Records Administration, 2020b).

The Federal Register is published daily each week, except for federal holidays, by the National Archives and Records Administration. It serves as the U.S. Government's official daily publication for rules, proposed rules, notices of federal agencies and organizations, and executive orders and other presidential documents (U.S. Government Publishing Office, 2020c).

Examples of Federal Register documents on USSF have been included in previously referenced presidential documents in this document. Proposed rules are also a critical component within the Federal Register with an example of one concerning USSF appearing September 15, 2020 proposed Army rule allowing USSF personnel to be eligible for burial at Arlington National Cemetery (U.S. Department of Defense, 2020b).

Interested individuals and organizations can issue public comments on proposed federal agency regulations in the Federal Register under the Administrative Procedure Act by the deadline date specified in individual Federal Register documents. The deadline for public comment on the aforementioned Army regulation was November 16, 2020. These public comments can influence how agencies enforce federal laws and regulations. Such comments are submitted through the regulations.gov/ website administered by (U.S. National Archives and Records Administration, 2020a; Shapiro, 2013; Balla, Beck, Meehan, Prasad, 2020).

Public comments submitted to regulations.gov range from conspiratorial complaints to detailed and insightful analyses of issues being addressed by proposed regulations. A March 26, 2020 Competitive Enterprise Institute comment on a January 13, 2020 Office of Management and Budget notice to 
federal agencies providing guidance for regulating artificial intelligence applications complained that USSF's establishment locked in a top-down approach toward private sector artificial intelligence and that USSF would inevitably alter freedoms and private commercial space activities and is likely to heavily influence technology and investment and evolution in a nascent economic sector. More public comments on USSF will occur as this force evolves (Competitive Enterprise Institute, 2020).

\section{Legislative Oversight}

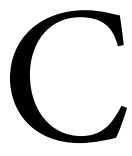

Iongressional oversight of USSF and other government agencies and their programs is authorized by Article I Sections 7-8 of the U.S. Constitution and is a critical component of documenting the successes, failures, and ambiguities inherent in these programs and informing public debate on these subjects. Committee members and their professional staff can possess and gain significant professional subject expertise of government agencies and programs within their jurisdiction (Zwirn, 1988; Curry, 2019).

\section{Congressional Committee Hearings}

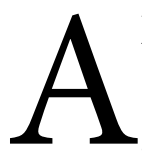

key example of congressional oversight occurs through congressional committee hearings in which witnesses from multiple government agencies, military armed service branches, and numerous other sources present legally sworn testimony representing multiple perspectives on operational and management topics confronting these programs which may affect congressional funding of these programs. There is considerable public access to these congressional committee hearings even on some sensitive national security topics (Lawrence, M.B. 2020, Davis, C.M., and Oleszek, W.J. 2020).

The congressional committees that will review USSF programs and activities are the House and Senate Armed Services Committees and their designated functional subcommittees and the House and Senate Appropriations Committees Subcommittees on Defense (U.S. Congress, Senate Committee on Armed Services, 2020b). Publicly accessible congressional committee hearings on USSF may occur as part of annual defense spending legislation or as part of oversight of USSF program component performance. An April 3, 2019 House Armed Services Committee Subcommittee on Strategic Forces hearing examined upcoming fiscal year priorities for national security space programs. Witnesses testifying included Government Accountability Office (GAO) official Cristina Chaplain, the Director of that agency's Contracting and National Security Audit Division; Assistant Secretary of Defense for Homeland Defense and Global Security Kenneth Rapuano, and Air Force Space Commander General John W. Raymond. Rapuano contended that USSF would catalyze space's transformation as a warfighting domain while also providing the undivided attention, advocacy, and leadership to develop personnel, doctrine, and capabilities necessary 
to maintain unrestricted access and to fight and win in space. Raymond noted the establishment of a space Rapid Capabilities Office at Kirtland, AFB and Chaplain observed that space acquisition activities would occur at agencies outside of USSF including the Missile Defense Agency, National Reconnaissance Office, and some military space service activities (U.S. Congress, House Armed Services Committee, 2020).

Rep. Mo Brooks (R-AL) asked Rapuano what happens to other military space entities such as Army and Space Missile Command, and Navy Space and Naval War Systems Command under DOD's USSF proposal. Rapuano replied that organic space capabilities necessary for individual services would stay within those services and that global capabilities beyond the capacity of individual services such as GPS would go to USSF. Brooks then asked whether existing military space capabilities such as the Army's Redstone Arsenal in Alabama would be able to use its existing space funding expertise and leverage in USSF. Rapuano responded saying USSF's Space Development Agency would not replace or displace existing institutions working in space development and acquisition (U.S. Congress. House Armed Services Committee, 2020).

\section{Congressional Support Agencies}

ongressional oversight and
analysis of USSF activities is
also conducted by congres-
Congressional Budget Office (CBO), Congressional Research Service (CRS), and Government Accountability Office (GAO). Established in 1975, CBO conducts objective and non-partisan analysis of the federal budget for Congress, prepares cost estimates for legislation reported by congressional committees, and prepares reports on the budgetary implications of federal programs (U.S. Congressional Budget Office, 2020a).

An example of a USSF-related CBO analysis was a June 2020 report on the costs of creating a Space National Guard within USSF. CBO prepared two cost scenarios with a smaller Space National Guard consisting of 1,500 existing personnel in the Air National Guard and Army National Guard being transferred to the new Space National Guard which $\mathrm{CBO}$ estimated would cause DOD to incur $\$ 100$ million in additional costs and one-time costs of \$20 million for constructing additional facilities. A scenario producing the creation of a larger Space National Guard consisting of 4,900-5,800 personnel would see DOD incur $\$ 385-\$ 490$ million in additional annual costs and onetime costs of $\$ 400$ - $\$ 900$ million for constructing new facilities and equipping new units (U.S. Congressional Budget Office, 2020b).

The Congressional Research Service (CRS) is a branch of the Library of Congress providing members of Congress and congressional committee and staff with unbiased reports on public policy issues, tailored confidential memoranda, briefings, and consultations, seminars and workshops, and expert congressional testimony (Con- 
gressional Research Service, 2020). CRS reports encompass the spectrum of public policy issues addressed by Congress. USSF has been the subject of many CRS reports. A representative example includes the April 6, 2020 memorandum Defense Primer: The United States Space Force. Contents of this document include providing legislative background on USSF's provenance, noting its estimated civilian and military personnel total is approximately 16,000 ; its field units including centers covering personnel, intelligence, doctrine, warfare, professional military education, and testing; and its major acquisition programs including National Security Space Launch, Global Positioning System products, Space-Based Overhead Persistent Infrared (OPIR) Systems, and Satellite Communications Projects (McCall, S. 2020).

GAO was established by Congress in 1921. It is an independent nonpartisan agency examining how tax dollars are spent and providing Congress and federal agencies with objective and reliable information to help the government safe money and work more efficiently. Individual members of Congress can request reports from GAO and upon accepting a request GAO assembles a team to initiate the audit work. This team meets with GAO experts, agency stakeholders, and management to design an audit method that is fact-based and supports findings and potential recommendations in a process typically lasting three months. Completed draft reports are sent to agencies for comment and most reports are publicly released about 14 days after receiving agency comments (U.S. Government Accountability Office, 2020a).

USSF's recent establishment means that there are not any reports yet explicitly covering its operations. However, there are numerous GAO reports available covering the management performance of DOD military space activities. An example is an April 2020 GAO report on the Air Force's planned Advance Battle Management System (ABMS). This system is intended to consist of a network of intelligence, surveillance, and reconnaissance sensors utilizing cloud-based data sharing to equip warfighters with battlespace awareness for air, land, sea, space, and cyber domains. The FY 2021 presidential budget request for this program is $\$ 302$ million.

GAO noted that the Air Force had established an ABMS management structure with unclear decision-making authorities; that there is no business case defining ABMS requirements; no plan to ensure that technologies are mature when needed; and no cost estimate or affordability analysis. Consequently, GAO recommended the Assistant Secretary of the Air Force for Acquisition, Technology, and Logistics direct the Chief Architect to develop a plan for attaining mature technologies for each ABMS development area with quarterly updates to Congress; prepare a cost estimate in accordance with cost estimate leading practices which is updated regularly with quarterly congressional updates; preparing program affordability analysis with quarterly congressional updates; and formalizing and docu- 


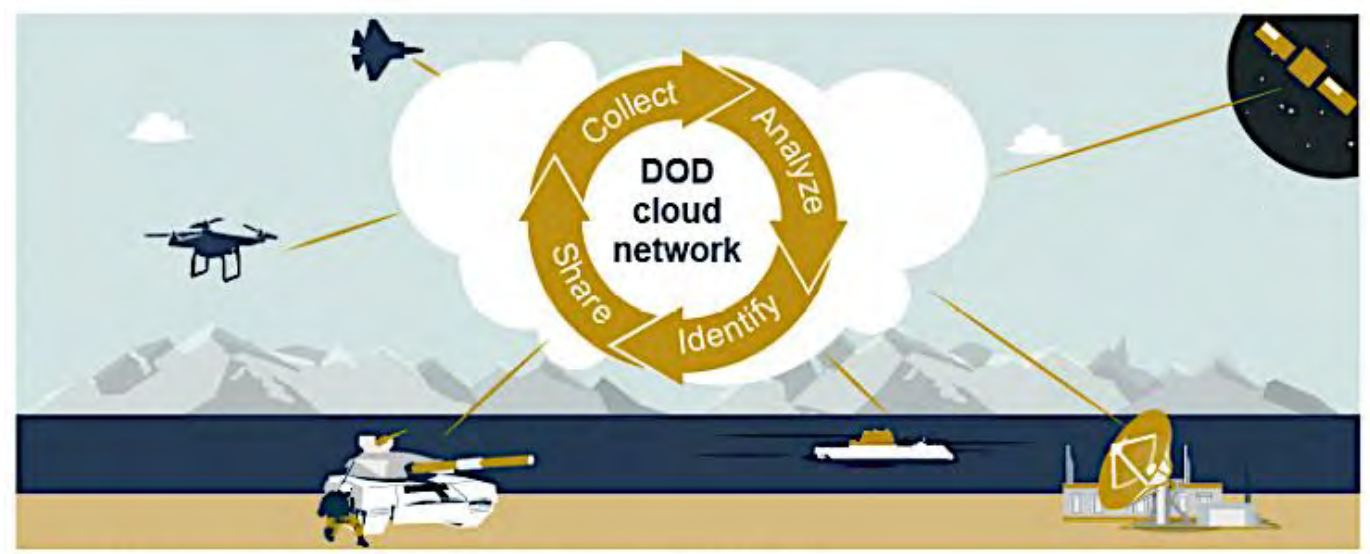

Source: GAO analysis of Department of Defense information. I GAO-20-389

Figure 1. Concept of Advanced Battle Management System

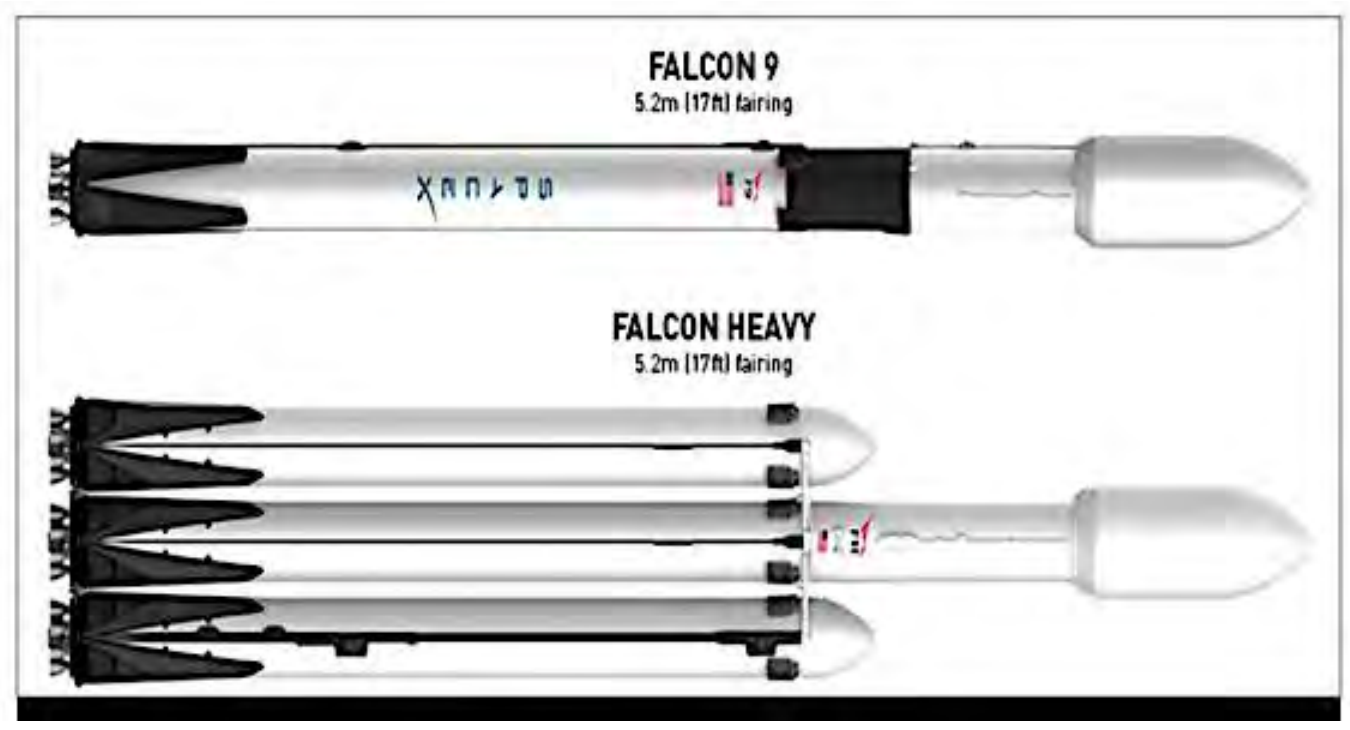

Figure 2. SpaceX's Falcon 9 and Falcon Heavy Launch Vehicles Source: SpaceX, January 2020.

menting acquisition authority and decision-making responsibilities within the Air Force involved in ABMS executing and planning. DOD agreed with all of GAO's recommendations although it is not uncommon for an agency whose programs are reviewed by GAO to disagree with report findings (U.S. Government Accountability Office, 2020b).

\section{DOD Oversight}

The Defense Department (DOD) also has entities conducting 1 oversight of the management performance of its own programs. One of these entities is its Office of Inspector General (DODIG). This agency, along with many other federal agency inspec- 
tors general, was established in 1978. Its purpose includes detecting, deterring, and preventing fraud, waste, and abuse in DOD programs and operations; promoting DOD's economy, efficiency, and effectiveness; and helping ensure ethical conduct throughout DOD. DOD's Inspector General is presidentially appointed and requires Senate confirmation and this office also has the authority to issue criminal penalties if fraud is committed by agency employees or private sector contractors (Friedes, 1992, Department of Defense Office of Inspector General, 2020(a), U.S. House of Representatives Office of Law Revision Counsel, 2020b).

An example of a DODIG report pertaining to USSF was released on September 4, 2020 and evaluated Air Force certification of space launch vehicles. This report's intent was determining whether Air Force Space and Missile Center (SMC) officials complied with the Air Force Launch Services New Entrant Certification Guide (NECG) when certifying launch system designs for National Security Space Launch (NSSL) SpaceX Falcon launch vehicles. DODIG concluded that SMC generally complied with Air Force Launch Services (NECG) and SMC Operating Instruction 17-001 when certifying the capabilities of SpaceX Falcon launch vehicles. DODIG expressed concern that SMC did not assess the risk of permitting previously used launch vehicle components on subsequent Falcon vehicle launches. Significant portions of this report were redacted for national security reasons and because SMC later provided DODIG with documentation not provided during the initial review causing DODIG to withdraw its initial recommendations (U.S. Department of Defense, Office of Inspector General, 2020b).

DOD's Director of Operational Test and Evaluation (DOT\&E) is located within the Office of the Secretary of Defense and was established in 1983. Its purpose is providing independent and objective assessments so military personnel have confidence in their equipment to fulfill mission requirements. Early and frequent testing is critical to ensuring combat credible systems and that such testing is relevant to the defense acquisition process. Its current priorities include securing software and cybersecurity, increasing prototyping and experimentation, integrating test and evaluation, improving test infrastructure, improving modeling and simulation use, ensuring a capable workforce, and ensuring DOT\&E relevance to DOD (Public Law 98-94, U.S. Department of Defense, Director of Operational Test and Evaluation, 2020a).

DOT\&E's annual report provides detailed coverage of military programs encompassing DOD, individual armed service branches, and multifunctional programs covering ballistic missile defense, live fire test and evaluation, cyber assessments, joint test and evaluation, and the Center for Countermeasures. It also provides contractor information, budgetary expenditures, candid assessments of program strengths and weaknesses, and recommendations for enhancing program quality. USSF programs will be covered by DOT\&E as are 
space-oriented programs of all armed service branches. The FY 2019 report opens by noting that cybersecurity test and evaluation testing and training for space-based systems remain the office's greatest challenges and that DOD intends to invest $\$ 100$ billion in space systems over the next decade. It also stressed that DOD is unable to adequately assess the operational effectiveness, survivability, and suitability of space-based systems (Department of Defense, Technology, and Evaluation, 2020b).

This report's assessment of the Air Force's Global Positioning System (GPS) noted that schedule slips from GPS segments had caused operational testing delays. This document acknowledged progress GPS had made but warned of significant remaining operational risks including more work being required to comprehensively replicate space threats, their effect on the space segment, mitigation efforts, and the strategy to conduct operational space segment testing using realistic threats and the Military GPS User Equipment program continues experiencing delays integrating new technology into lead platforms and in developing final software and hardware builds by vendors (Department of Defense, Technology, and Evaluation, 2020b).

This document also described the Air Force Space Fence (SF) program which is a surveillance-based S-band radar system detecting, tracking, identifying and characterizing man-made and naturally occurring Earth-orbiting space objects. SF is currently deploying at the Kwajalein Atoll and the Reagan
Test Site Operations Center in Huntsville, AL with a forthcoming unfunded site scheduled for Australia. DOT\&E noted that SF had demonstrated the capability to many small previously untracked or cataloged objects but that the presence of only one sensor site it lacks the power or coverage to be able to continuously track or maintain awareness of small objects (Department of Defense, Technology, and Evaluation, 2020b).

\section{Public Opinion Polls}

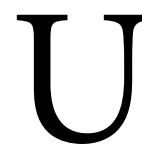
SSF's ongoing political and economic viability depends on continuing public support and funding for its activities. Three polls in 2018-2019 reflect mixed public opinion on the desirability of establishing a new armed service branch. An August 2018 CNN poll of 1,002 respondents asked if the U.S. should establish a new military branch to protect U.S. assets in space: $37 \%$ said yes, $55 \%$ said no, and $8 \%$ had no opinion (Roper Center for Public Opinion Research, 2018).

A May 2019 Pew Research Center poll found asking 1,087 individuals whether they approved or disapproved of establishing a new military branch called the Space Force received the following responses:

Strongly Approve 10\%

Somewhat Approve 26\%

Somewhat Disapprove 27\%

Strongly Disapprove 33\%

No Answer 4\% (Roper Center for Public Opinion Research, 2019a). 


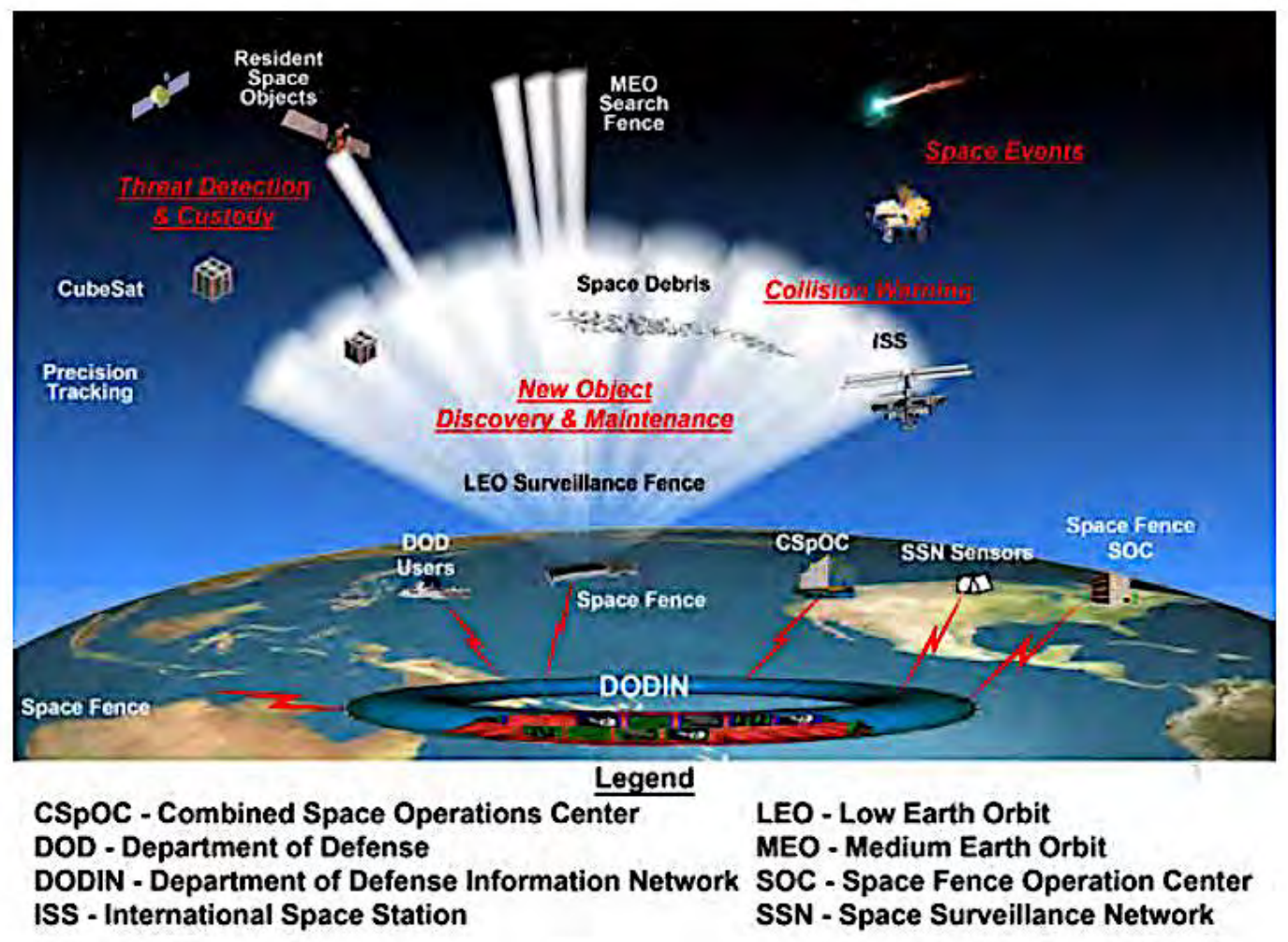

Figure 3. Components of the Space Fence

A May-June 2019 Pew Research Center poll asking 1,284 individuals whether they approved or disapproved of establishing a Space Force produced these responses:

Strong Approve 15\%

Somewhat Approve 30\%

Somewhat Disapprove 22\%

Strongly Disapprove 31\%

No Answer 2\% (Roper Center for Public Opinion Research, 2019b).

\section{Conclusion}

7 his article has demonstrated that there is a significant corpus of publicly accessible research on

USSF to facilitate public knowledge, Johnson-Freese, 2017).

discussion, and debate on this entity and its multiple diplomatic, economic, military, and political implications for the U.S. and its allies. It has shown that discussion of possible U.S. military involvement in space has generated debate and controversy for multiple decades. USSF will transform U.S. civilian and military law and the legal architecture of international law (Tepper, 2020). Numerous scholarly works have documented how increasing U.S. and international military activity in space will have global repercussions on the economies and societies of world nations and the conduct of military operations (DeBlois, 1999; Dolman, 2001; Brown, 2006, Chapman, 2008; Dolman 2001; 
Publicly accessible government communications and literature on USSF document how this armed service may potentially impact the U.S. economy, business opportunities, the geographic dispersion of government contracting, domestic and international law, U.S. foreign relations, the successes, failures, and ambiguities of program performance, and the financial costs of USSF in comparison when other governmental funding priorities. These information resources also provide the opportunity to inform the public about the need for the U.S. and its allies to address the increasing national security importance of space due to the emergency of great power rivals like China and Russia who seek to use space to disrupt, disable, and destroy U.S. civilian economic and military dependence on space (U.S. Space Force, 2020d; U.S. Department of Defense, 2020a).

In an August 4, 1822 letter former President James Madison wrote
"Knowledge will forever govern ignorance: and a people who mean to be their own Governors, must arm themselves with the power which knowledge gives" (Madison, J. 1822). The creation of the first new U.S. military branch in over seven decades means Americans and the world must educate themselves on the multifaceted aspects of USSF and how it will impact civilian and military policy in subsequent decades. USSF will also impact our personal economic lives and governmental finance as well. If Americans desired to be informed about USSF activities they must utilize the publicly accessible literature on this subject to inform themselves when communicating with their congressional representatives, participate in the federal regulatory process, engage in commercial activities, and participate in emerging national and international debate on space's increasing military importance.

\section{References}

Balla, S.J., Beck, A.R., Meehan, E., Prasad, A. 2020. "Lost in the Flood? Agency Responsiveness to Mass Comment Campaigns in Administrative Rulemaking." Regulation \& Governance, https://doi.org/10.1111/rego.12318

Brown, K.K., ed. 2006. Space Power Integration: Perspectives from Space Weapons Officers. Maxwell AFB, AL: Air University Press, https://www.airuniversity.af.edu/ Portals/10/AUPress/Books/B_0105_BROWN_SPACE_POWER_INTEGRA TION.pdf

Cesul, B.T. 2014. "A Global Space Control Strategy." Air and Space Power Journal, 28 (6) (November-December): 69 
Chapman, B. 2008. Space Warfare and Defense: A Historical Encyclopedia and Research Guide. Santa Barbara: ABC-CLIO

Competitive Enterprise Institute. 2020. "Artificial Intelligence Will Merely Kills Us, Not Take Our Jobs.” https://www.regulations.gov/document?D=OMB-2020 $-0003-0002 ; 5$

Congressional Research Service. 2020. "About this Collection." https://crsreports. congress.gov/Home/About; 1

Curry, J.M. 2019. "Knowledge, Expertise, and Committee Power in the Contemporary Congress." Legislative Studies Quarterly, 44(2): 203-237

Davis, C.M., Oleszek, W.J. 2020. Congressional Oversight Manual. Washington, D.C.: Library of Congress, Congressional Research Service, https://crsreports.con gress.gov/product/pdf/RL/RL30240

DeBlois, B.M. 1999. Beyond the Paths of Heaven: The Emergence of Space Power Thought: A Comprehensive Anthology of Space-Related Masters Research Produced by the School of Advanced Airpower Studies. Maxwell AFB, AL. https://purl.fdlp. gov/GPO/LPS20368

Dolman, E. 2001. Astropolitik: Classical Geopolitics in the Space Age. Portland, OR: Frank Cass Publishers

Friedes. T. 1992. "Inspector General Reports as Instruments of Government Accountability." Government Information Quarterly, 9(1): 53-64

Grant, Dustin L, Neil, M.J. 2020. The Case for Space: A Legislative Framework for an Independent United States Space Force. Maxwell AFB, AL: Air University Press, 44; https://purl.fdlp.gov/GPO/gpo137316

Grants.gov. 2018. "FAS9453-17-S-005 Research Options for Space Enterprise Technologies (ROSET) Department of Defense AFRL Kirtland, AFB. https://www. grants.gov/web/grants/search-grants.html?keywords=space\%20force; 1-2.

Grosselin, Kenneth. 2020. "A Culture of Military Spacepower." Air and Space Power Journal, 34(1), (Spring): 75-77, 81-83; https://www.airuniversity.af.edu/Portals /10/ASPJ/journals/Volume-34_Issue-1/SEA-Grosselin.pdf

Hayden, Dale L. 2014. “The Search for Space Doctrine's War-Fighting Icon.” Air and Space Power Journal, 28 (6) (November-December): 56, 61; https://www. airuniversity.af.edu/Portals/10/ASPJ/journals/Volume-28_Issue-6/V-Hayden.pdf 
House Report 116-453. 2020. Department of Defense Appropriations Bill, 2021... Together With Minority Views. Washington, D.C.: GPO, 96, 225, 296, 301 https:// www.govinfo.gov/content/pkg/CRPT-116hrpt453/pdf/CRPT-116hrpt453.pdf.

Johnson-Freese, J. 2017. Space Warfare in the 21 ${ }^{\text {st }}$ Century: Arming the Heavens. London: Routledge

King, Matthew T. 2016. "Sovereignty's Gray Area: The Delimitation of Air and Space in the Context of Aerospace Vehicles and the Use of Force." Journal of Air Law and Commerce, 81(3): 377-497; https://scholar.smu.edu/cgi/viewcontent. cgi? article $=1016 \&$ context $=$ jalc

Laurie, Clayton D. 2001. Congress and the National Reconnaissance Office. Washington, D.C.: Office of the Historian, National Reconnaissance Office. https://purl. fdlp.gov/GPO/gpo63132

Lawrence, M.B. 2021. "Congress' Domain: Appropriations, Time, and Chevron." Duke Law Journal, 70 (5)(February 2021): 1057-1109; https://dlj.law.duke.edu/ article/congresss-domain-lawrence-vol70-iss5/

McCall, S. 2020. Defense Primer: The United States Space Force. Washington, D.C.: Congressional Research Service, https://crsreports.congress.gov/product/pdf/IF/ IF11495; 1-2.

Madison, J. 1822. To W.T. Berry Mad MSS. Washington, D.C.: Library of Congress, https://www.loc.gov/resource/mjm.20_0155_0159/?sp=1\&st=text; 1 .

Miller, Gregory D. 2019. "Space Pirates, Geosychronous Guerillas, and Nonterrestrial Terrorists: Nonstate Threats in Space." Air and Space Power Journal, 33(3) (Fall): 33-51; https://www.airuniversity.af.edu/Portals/10/ASPJ/journals/Volume33_Issue-3/F-Miller.pdf

Mowthorpe, Matthew J. 2001. "The United States Approach to Military Space During the Cold War." Air and Space Power Chronicles, https://www.airuniversity. af.edu/Portals/10/ASPJ/journals/Chronicles/mowthorpe.pdf

Public Law 80-253. National Security Act of 1947. 61 U.S. Statutes at Large, 502504; https://www.loc.gov/law/help/statutes-at-large/80th-congress/session-1/c80s 1 ch343.pdf

Public Law 98-94. National Defense Authorization Act, 1984. 97 U.S. Statutes at Large, 614, 684-686. https://www.govinfo.gov/content/pkg/STATUTE-97/pdf/ STATUTE-97.pdf 
Public Law 116-92. National Defense Authorization Act For Fiscal Year 2020. 133 U.S. Statutes at Large 1561-1563, 2074. https://www.congress.gov/116/plaws/pub 192/PLAW-116publ92.pdf

Ramey, Robert A. 2000. "Armed Conflict on the Final Frontier: The Law of War in Space." Air Force Law Review, 48 https://www.afjag.af.mil/Portals/77/documents /AFD-081204-031.pdf;1-158

Roper Center for Public Opinion Research. 2018. CNN Poll: August 2018-Poll 7 Question 58. Ithaca, NY: Roper Center for Public Opinion Research

Roper Center for Public Opinion Research. 2019a. Pew Research Center's American Trends Panel Poll, Question 12. Ithaca, NY: Roper Center for Public Opinion Research

Roper Center for Public Opinion Research. 2019b. Pew Survey of Veterans, Question 12. Ithaca, NY: Roper Center for Public Opinion Research

Ruffner, Kevin C., ed. 1995. Corona: America's First Satellite Program. Washington, D.C.: CIA Center for the Study of Intelligence. https://purl.fdlp.gov/GPO/LPS9944

Shapiro, Stuart. 2013. "When Will They Listen?" Public Comment and Highly Salient Regulations.” Mercatus Working Paper, https://papers.ssrn.com/sol3/papers. cfm?abstract_id $=3191327$

"Space Policy Directive 4 of February 19, 2019 Presidential Documents: Establishment of the United States Space Force" 2019. Federal Register, 84(37), (February 25): 6049-6052. https://www.govinfo.gov/content/pkg/FR-2019-02-25/pdf/201903345.pdf

"Space Policy Directive 5 of September 4, 2020 Presidential Documents: Cybersecurity Principles for Space Systems.” 2020. Federal Register, 85 (176), (September 10): 56155-56158. https://www.govinfo.gov/content/pkg/FR-2020-09-10/pdf/ 2020-20150.pdf

Spires, David N. 2007. Beyond Horizons: A History of the Air Force in Space, 19472007. $2^{\text {nd }}$ ed. Peterson Air Force Base, CO: United States Air Force. https://www. airuniversity.af.edu/Portals/10/AUPress/Books/B_0063_SPIRES_BRADLEY_ STURDEVANT_ECKERT_BEYOND_HORIZONS.pdf

System for Award Management. 2020_https://www.sam.gov/SAM/pages/public/ generalInfo/aboutSAM.jsf 
Tepper, E. 2020. “Space Force One: The Complex of Space Warfare." Social Science Research Network, https://papers.ssrn.com/sol3/papers.cfm?abstract_id=3672841

Townsend, Brad. 2019. "Space Power and the Foundations of an Independent Space Force." Air and Space Power Journal, 33(4) (Winter): 12, 14-15, 17, 20, 22; https://www.airuniversity.af.edu/Portals/10/ASPJ/journals/Volume-33_Issue-4/ F-Townsend.pdf

U. S. Congressional Budget Office. 2020a. "Introduction to CBO." Washington, D.C.: CBO, https://www.cbo.gov/about/overview; https://www.cbo.gov/system/ files/2020-06/56374-CBO-SpaceNationalGuard.pdf; 1

U.S. Congressional Budget Office. 2020b. "Costs of Creating a Space National Guard." Washington, D.C.: CBO, 1;

U.S. Congress. House Committee on Armed Services. Fiscal Year 2020 Priorities for National Security Space Programs. Washington, D.C.: GPO, https://purl.fdlp. gov/GPO/gpo131496; 2, 4-5, 12

Report to Accompany S... Department of Defense Authorizations. Washington, D.C.: Senate Committee on Armed Services, 180, 373, 444-445, 592, 641, 671 https:// www.armed-services.senate.gov/imo/media/doc/FY\%202021\%20NDAA\%20 -\%20Report.pdf

U.S. Congress. Senate Committee on Armed Services. 2020b. "Committee History: Committee Jurisdiction.” https://www.armed-services.senate.gov/about/history

U.S. Department of Defense. 2017. DOD Directive 5100.96: DOD Space Enterprise Governance and Principal DOD space Advisor (PDSA). (Washington, D.C.: June 9, 2017): 1, 6; https://www.esd.whs.mil/Portals/54/Documents/DD/issuances/dodd/ 510096_dodd_2017.pdf

U.S. Department of Defense. 2020a. Defense Space Strategy Summary. Washington, D.C.: 1, 6-9; http://purl.fdlp.gov/GPO/gpo140493.

U.S. Department of Defense. 2020b. "Department of the Army 32 CFR 553 Army Cemeteries." Federal Register, 85 (179) (September 15): 57640-57659; https://www. govinfo.gov/content/pkg/FR-2020-09-15/pdf/2020-17801.pdf

U.S. Department of Defense. Director of Operational Test and Evaluation. 2020a. "About: Focus Areas." https://www.dote.osd.mil/About/Focus-Areas/; 1.

U.S. Department of Defense. Director of Operational Test and Evaluation. $2020 \mathrm{~b}$. 
"FY 2019 Annual Report, (Washington, D.C.: DOT\&E, 2019); i-iii, 189; 201-202; https://www.dote.osd.mil/Portals/97/pub/reports/FY2019/other/2019DOTEAn nualReport.pdf?ver=2020-01-30-115634-877

U.S. Department of Defense. Office of Inspector General. 2020a. "Our Mission." Washington, D.C.: DODIG, 1; https://www.dodig.mil/About/Mission/

U.S. Department of Defense. Office of Inspector General. 2020b. Evaluation of the Air Force's Certification of Space Launch Vehicles. Washington, D.C.: DODIG, i-ii, 27-29; https://media.defense.gov/2020/Sep/09/2002493542/-1/-1/1/ DODIG-2020-126_REDACTED\%20V2.PDF

U.S. Government Accountability Office. 2020a. Reports and Testimonies: The Report Process. Washington, D.C.: GAO, 1-2; https://www.gao.gov/about/what-gaodoes/reports-testimonies/

U.S. Government Accountability Office. 2020b. Defense Acquisitions: Action is Needed to Provide Clarity and Mitigate Risks of the Air Force's Planned Advance Battle Management System. Washington, D.C.: GAO, 1, 5, 12, 14, 17-19, 22; https:// www.gao.gov/assets/710/706165.pdf

U.S. Government Publishing Office. 2020a. "About the Code of Federal Regulations." https://www.govinfo.gov/help/cfr; 1-3

U.S. Government Publishing Office. 2020b. "Electronic Code of Federal Regulations Title 32 Subtitle A Chapter VII Subchapter A," https://www.ecfr.gov/cgi-bin/ text-idx?SID =07abc784860da460158b1d78421ae4ca\&mc=true\&tpl=/ecfrbrowse/ Title32/32cfrv6_02.tpl\#0.

U.S. Government Publishing Office. 2020c. "About the Federal Register." https:// www.govinfo.gov/help/fr\#about; 1-2

U.S. House of Representatives. Office of Law Revision Counsel. 2020a. United States Code, https://uscode.house.gov/view.xhtml?path=/prelim@title10/subtitleD /part1/chapter908\&edition=prelim; 1-2

U.S. House of Representatives. Office of Law Revision Counsel. 2020b. Inspector General Act of 1978, https://uscode.house.gov/view.xhtml?path=/prelim@title5/ title5a/node20\&edition $=$ prelim

U.S. National Archives and Records Administration. 2020. "Administrative Procedure Act 5 USC 552." https://www.archives.gov/federal-register/laws/administra tive-procedure/552.html 
U.S. National Archives and Records Administration. 2020b. "Email from Office of the Federal Register," October 13, 2020

U.S. Space Force, 2020. “USSF Organization.” https://www.spaceforce.mil/AboutUs/About-Space-Force/Space-Force-Organization/

U.S. Space Force, 2020b. “USSF Directorates." https://www.spaceforce.mil/AboutUs/USSF-Industry-Partners/

U.S. Space Force, 2020c. "USSF Locations." https://www.spaceforce.mil/About-Us/ Space-Force-Locations/

U.S. Space Force, 2020d. Space Capstone Publication Spacepower Doctrine for Space Forces. (Washington, D.C.): iii, xiii, 52, 54-55; http://purl.fdlp.gov/GPO/ gpo143383.

U.S. Space Force, 2020e. "Space Force Awards National Security Space Launch Phase 2 Launch Service Contracts to United Launch Alliance, LLC (ULA) and Space Exploration Technologies Corporation (SpaceX); 1-2. https://www.spaceforce.mil/News/Article/2305278/space-force-awards-national-security-spacelaunch-phase-2-launch-service-contra/

Usaspending.gov/ 2020. "Delivery Order (DO) PIID FA251718F9021." https://www.usaspending.gov/award/CONT_AWD_FA251718F9021_9700_ GS00Q14OADS133_4732; 1-2

White House, "Establishment of United States Space Command as a Unified Combatant Command: Memorandum for the Secretary of Defense," Federal Register 83 (245)(December 21): 65483; https://www.govinfo.gov/content/pkg/FR-201812-21/pdf/2018-27953.pdf.

Whitney, Jonathan; Thompson, K, Park, J.H. (2019). "A Plan for a US Space Force: The What, Why, How, and When." Air and Space Power Journal, 33(3), (Fall): 84, 87-88; 91-92. https://www.airuniversity.af.edu/Portals/10/ASPJ/journals/Vol ume-33_Issue-3/V-Whitney_et_al.pdf.

Yoo, John. 2020. "Rules for the Heavens: The Coming Revolution in Space and the Laws of War." University of Illinois Law Review, (1): 123-194; https://illinoislawre view.org/wp-content/uploads/2020/02/Yoo.pdf.

Zwirn, Jerrold. 1988. Congressional Publications and Proceedings: Research on Legislation, Budgets, and Treaties. $2^{\text {nd }}$ ed. Littleton, CO: Libraries Unlimited. 